\title{
DETERMINATION OF POLYCYCLIC AROMATIC OF HYDROCARBONS (PAHs) BENZO [a] PYRENE LEVEL IN HEAT TREATED FOOD FROM EGYPTIAN MARKET BY GC AND HPLC-FLUORESENCES DETECTION Manal A. Atwa
}

Regi.Center for Food and Feed,Agri. Res. Center.

\begin{abstract}
This study was aimed to measure benzo(a)pyrene $(\mathrm{BaP})$ as the most important one of polycyclic aromatic hydrocarbons (PAHs) in many kind of foods by GC and HPLC-FD.

The detection was carried out for the presence of benzo(a)pyrene in more than 90 food samples collected from retail stores in Egyptian markets (including vegetable oil, meat, cheese ,fish, coffee..etc.) in order to investigate the effect of processing treatments such as hot and cold pressing of prepared oils, strength of roasting process of coffee, smoking treatments and direct exposure of food to temperature on the formation of benzo(a)pyrene.

The results showed that Benzo(a)pyrene content in smoked samples were varied from high level in smoked herring fish to low in canned tuna samples. Also; it was notable that smoked processed beef, sausages and salmon had a low BaP values. Around $30 \%$ of the smoked samples examined in this study had BaP levels exceeded than the acceptable limit as specified by the European Commission (E.C, 2005).

The amount of BaP detected in more than 24 coffee, tea and cocoa were higher than the permissible limit (1ppb) set by European Commission(E.C, 2005). In eighteen coffee samples, fourteen samples had upper values for the exceeding. The content of $\mathrm{BaP}$ in strong roasting coffee samples (dark) was higher than moderate or lighter roasting process. The highest value in this category was in flavored green tea; while in the cocoa powder there was a negligible amount of $\mathrm{BaP}$.

The levels of $\mathrm{BaP}$ in 28 oil samples showed that the highest value was reported in roasted sesame oil samples from local market while the least was reported in cold press olive oil samples from local market. In butter, vegetable oil associated with pickles and cheese there were no detectable level of $\mathrm{BaP}$; In cold press olive oil, flax seed oil and sesame levels of BaP were significantly lower as compared to the thermal press oils samples .Olive-pomace oil contained high levels of $\mathrm{BaP}$.

Analyzed 10 vegetable oil associated with canned fish; the smoked sardine and tuna contained the highest levels of $\mathrm{BaP}$. In four samples (tuna, mackerel, sardines and anchovies) showed a BaP level less than $1 \mu \mathrm{g} / \mathrm{kg}$.

Among twelves charcoal barbecued samples analyzed for $\mathrm{BaP}$ and $50 \%$ of the samples were exceeding the level set by European Commission regulations. BaP charcoal barbecued lamb meat had around three fold the BaP level of beef meat sample. Charcoal barbecued (sausages and lamb) samples contained high levels of $\mathrm{BaP}$. Liver and shrimp samples showed moderate level of BaP; while the minced meat (kofta ) sample gave high ratio of $\mathrm{BaP}$.

BaP contents 10 times lower in fish sample than fish skin sample; also, the chicken skin contained BaP three times higher than chicken meat.

Fifteen samples include nuts, dried fruits, cereals and chocolates, infant formula showed content of BaP comply with the EU regulations. While in dark soya sauce sample, the $\mathrm{BaP}$ was relatively higher than the limit set by EU regulations.
\end{abstract}


Manal A. Atwa.

Keywords:Vegetable oil, coffee, Polycyclic aromatic hydrocarbon ,HPLC-FD,GC-FID ,Benzo(a)Pyrene, Coffee powder, Roasting, Smoked, Solid phase extraction( SPE), Charcoal barbecued.

\section{INTRODUCTION}

Hydrocarbons of polycyclic aromatic compounds (PAH's) are a group of aromatic rings. The five fused rings are known as Benzo-[a]-Pyrene. Some of PAHs are: benz[a]anthracene, benzo[a]pyrene, benzo[b] fluoranthene, benzo[k] fluoranthene, chrysene, dibenz[a,h] anthracene, and indeno (Howard et al., 1996) pyrene (García-Falcón et al., 1999 ). Nevertheless, benzo[a]pyrene (BaP) is usually taken as marker substance for PAH exposure in general because of its extremely high carcinogenic potential (Laffon at al.,1997) BaP is a member of polycyclic aromatic hydrocarbons (PAHs) which are a large group of organic compounds with mutagenic and carcinogenic properties (Ramalhosa et al., 2009). Benzo[a]pyrene is the only polycyclic aromatic hydrocarbon with sufficient toxicological evidence to allow the setting of a guideline (Moret et al., 2005 and Yusty and Davina, 2005).

Contamination of foodstuffs by PAHs can occur at source through atmospheric deposition on crops (Culotta et al., 2002), or from preservation of food by drying and cooking procedures. This contamination is enhanced during smoking and intense thermal processing (Chen and Chen, 2001). During intense thermal processing the contamination occurs by direct pyrolysis of food nutrients (Orecchio and Papuzza, 2008).

Animal studies have shown that dietary intake of $\mathrm{BaP}$ causes increased levels of tumors at several sites, particularly in the upper gastrointestinal tract. Humans can be exposed to $\mathrm{BaP}$ through different routes. For the general population non-smokers, the major routes of exposure are from food consumption. Most individuals are predominantly exposed to PAHs from dietary sources (Bordajandi et al., 2008).

Food can be contaminated from environmental sources, industrial food processing and from certain home food preparation.

SCF (Scientific Committee on Food),( 2002) estimated a maximum daily intake of benzo[a]pyrene from food of approximately $6-8 \mathrm{ng} / \mathrm{kg} \mathrm{b.w}$. per day for a person weighing $70 \mathrm{~kg}$ but $5 \mu \mathrm{g} / \mathrm{kg}$ (EU regulations).

After eating BaP, our body attempts to rid of the foreign substance by converting it into a water-soluble compound for metabolism, a diol expoxide. This compound, in turn, reacts with and binds to cellular DNA. Consequently, diol expoxide alters DNA and mutates genes (Hecht et al.), (2010). BaP has been shown to affect both the development and response of $T$ and $B$ cells in the immune system (Chan et al., 2011). It can decrease epididymis sperm quality, possibly by disturbing testosterone levels, and StAR may be a major steroidogenic protein that is targeted by $\mathrm{B}[\mathrm{a}] \mathrm{P}$ or other $\mathrm{PAHs}$. Research has also shown that PAHs could be transferred from their mothers to newborns and young infants, and cause brain and behavior toxicity (Leadon et al., 1988 and ATSDR., 1996). 
The International Agency for Research on Cancer (IARC) 1987, has upgraded its overall evaluation of $\mathrm{B}[\mathrm{a}] \mathrm{P}$ from group $2 \mathrm{~B}$ (possibly carcinogenic to humans) to 1 (carcinogenic to humans).

The presence of PAHs in coffee has also been reported and it has been suspected to be due to either a contamination of green coffee beans during the drying step or an endogenous formation in the coffee beans during the roasting process (Houessou et al., 2005 and Houessou et al., 2008).

Therefore, this study has been carried out to evaluate the level of $\mathrm{B}[\mathrm{a}] \mathrm{P}$ in 90 selected foods to supply new information on $\mathrm{B}[\mathrm{a}] \mathrm{P}$ levels in a variety of foods from Egypt.

\section{MATERIALS AND METHODS}

MATERIALS:

Reagents: N-Hexane (HPLC grade), Dichloromethane (HPLC grade), Acetonitrile (HPLC grad); Benzo (a)pyrene $(100 \mathrm{mg} / \mathrm{ml})$; PTFE syringe filter $(0.22 \mu \mathrm{m})$; SPE cartridge.

Instruments: HPLC-FD dionex ultimate 3000 , GC clarius 600 perkin elmer, Rotary evaporator, Ultrasound instrument, 24 Position Vacuum manifold SPE instrument, centrifuge .

Chemicals: Benzo[a]pyrene standard from Sigma-Aldrich Chemie (Steinheim, Germany) had a minimum of $97 \%$ purity. A solutions stock containing $100 \mathrm{mg}$ and $100 \mathrm{mg}$ of $\mathrm{BaP}$ were prepared in hexane, ACN and DMSO dimethyl sulfoxide then stored at $4^{\circ} \mathrm{C}$ in volumetric flacks (with glass stoppers) wrapped in aluminum foil to avoid possible light degradation. The $\mathrm{BaP}$ standard was prepared by appropriate dilutions of these stock solutions.

In this study a detection was carried out for the presence of benzo(a)pyrene $\mathrm{BaP}$ in more than 90 samples collected from retail stores in Egyptian markets include olive oil prepared by hot and cold pressing and many types of vegetable oil such as corn oil, sunflower oil, sesame oil, coconut oil, palm oil, soya oil, canola oil, , grape seed oil, toasted sesame oil, and mixed vegetable oil, (oil associated with canned fish) as well as soya sauce (imported and from local production available on the market). Cold and heat press olive and sesame oil samples were examined to compare the two processes. Barbequed food samples (meat, chicken, shrimp, bread, corn and fish ) were also investigated.

Also, BaP were determined in selected samples of tea, cocoa and roasted coffee powder; in order to evaluate the effect of high temperature of roasting processes on benzo (a) pyrene content in comparison to low roasting temperature and green coffee seeds.

Smoked salmon, herring, processed meat, cheese, dried fruits, chocolates, and cocoa powder also were analyzed to benzo (a) pyrene detection.

The values set in the result tables is average of the measured concentrations of $\mathrm{BaP}$ in replicate samples (three times in separate runs). 
Manal A. Atwa.

\section{METHODS:}

The present study was carried out to measure $\mathrm{BaP}$ which is the most important one of PAHs in many kind of foods by GC and HPLC-FD. The analysis of PAHs at these low concentration levels is a major challenge to analytics, especially due to the laborious removal of the complex lipid matrix for chromatographic detection. To extract hydrophobic Benzo(a)pyrene from oil matrix which is also hydrophobic, hexane was chosen as the best solvent to dissolve samples after investigation Liquid-liquid extraction was applied to extracted benzo (a) pyrene (BaP) and two methods were generally applied for PAH extraction from samples. the first of which is a combination of liquidliquid extraction (LLE), typically using Acetonitrile(ACN) or DMSO dimethyl sulfoxide followed by back-extraction with hexane with a solid phase extraction (SPE) step, for which normal-phase as well as reversed-phase (RP) solid phases can be applied (Balenovic, et.al 1995; Van Stijn, et. al 1996 and Pupin,1996) Extraction of BaP was achieved using $\mathrm{C} 18$ solid phase extraction (SPE) prior to analysis by gas chromatography and HPLC-FD.

\section{Sample treatment}

Extraction and clean-up: Sample was weighed $(3 \mathrm{~g}$ to $5 \mathrm{~g}$ ) depending on the particle size of sample was weighed in a centrifuge tube with sealing cap and extracted with three portions of $10 \mathrm{ml}$ Acetonitrile ACN, shaking vigorously for $3 \mathrm{~min}$. After each extraction, the sample was centrifuged at $2500 \mathrm{rpm}$ for $10 \mathrm{~min}$ to separate the layers, drawing off upper layer with pipette. The combined ACN extracts $(30 \mathrm{ml})$ were concentrated to dryness in rotary evaporator, and the residue was dissolved in $5 \mathrm{ml}$ of hexane; which was then passed onto a SPE cartridge and eluted with $10 \mathrm{ml}$ of hexane to wash the cartridge and $5 \mathrm{ml}$ dichloromethane to elute the benzo(a)pyrene out. The hexane elute was evaporated to dryness and the residue was dissolved in $1 \mathrm{ml}$ of acetonitrile to reconstitute the sample. In addition, if some samples kind contained more impurities which was need to be treated with SPE again; In the case of heavy matrix sample may use silica gel post- extraction cleanup; which the concentrated extracts were purified by column chromatography on silica gel, as described by Hossain et al. (2009). then filtered through $0.22 \mathrm{~mm}$ pore-size PTFE filters. The detection was carried out on GC with FID detection; Using standard capillary column and quantitation was done. The applied extraction method allowed handling over 90 samples using GC perkin elmer clarius 600 with a programmable FID detector to determine the content of the heavy polycyclic aromatic hydrocarbons (PAHs); benzo(a)pyrene, also detection on the HPLC-FD Dionex 3000 Ultimate carried to confirm results using HPLC column C18 $5 \mathrm{u}$ hypersil $15 \mathrm{~cm}$ on exc:254 nm and the emission $406 \mathrm{~nm}$; the mobile phase was hexane $99.5 \%$ to dichloromethane $0.5 \%$ on flow rate $0.6 \mathrm{ml} / \mathrm{min}$. there was no significant differences between the results of the two instruments.

After $10 \mathrm{~s}$ ultrasound treatment and filtration by $0.22 \mu \mathrm{m}$ PTFE Syringe filter, the sample was ready for GC or HPLC Injection. 


\section{RESULTS AND DISCUSSION}

With the current legislation prescribing benzo[a]pyrene to be used as an indicator for general PAH contamination; the relevance of such use was tested by calculating concentrations of the other PAHs in the absence of benzo[a]pyrene. The European Union Commission Regulation (EC) No 2008/2005 set maximum limits of PAHs in food and forces the producers to a more strict monitoring of PAH as there is the limitation of benzo(a)pyrene in all types of food $(5(\mu \mathrm{g} / \mathrm{kg})$.

Table: (1) The BaP concentrations in experimental kinds of different types of food samples

\begin{tabular}{|l|c|c|c|}
\hline Category of & Samples & \multicolumn{3}{|c|}{ Concentrarion of BaP $(\boldsymbol{\mu g} / \mathbf{k g})$} \\
\cline { 3 - 4 } smoked samples & tested & Minimum & Maximum \\
\hline Smoked cheese & 2 & ND & 0.16 \\
\hline Smoked cooked cheese & 3 & ND & 8.72 \\
\hline Smoked processed sausages & 2 & 0.2 & 1.52 \\
\hline Smoked turkey & 2 & 0.5 & 3.6 \\
\hline Smoked salmon & 2 & 1.22 & 5.2 \\
\hline Smoked tuna & 2 & 0.3 & 10.86 \\
\hline Local smoked herring & 1 & - & 17.6 \\
\hline Imported smoked herring & 2 & 1.2 & 4.9 \\
\hline Smoked processed beef & 2 & ND & 0.76 \\
\hline
\end{tabular}

Benzo[A]pyrene concentration in smoked samples ranged from 0.16 to $17.6 \mu \mathrm{g} / \mathrm{kg}$ among the samples as shown in Table(1). The least BaP concentration was recorded in smoked imported cheese sample while the highest was recorded in smoked herring fish sample obtained from local market. Also, the smoked canned tuna had a high level of BaP $(10.86 \mu \mathrm{g} / \mathrm{kg})$. It was notable that smoked processed beef, sausages and salmon had a low $\mathrm{BaP}$ values of $(0.76,0.2$ and 1.22 respectively).

Around $50 \%$ the smoked samples examined in this study, had $\mathrm{BaP}$ levels which exceeded the acceptable limit of $5 \mu \mathrm{g} / \mathrm{kg}$ as specified by the European Commission (E.C, 2005).

Smoked fish constitute an important and significant part of the human diet. Nutritionally this is due to their desirable sensory properties, high nutritional value and abundance of lipids rich in $n-3$ fatty acid residues. The findings from the present study indicated that the wood smoke used in smoking process of fish contributed to contamination of the fish with $\mathrm{BaP}$. The variation in the levels of $\mathrm{BaP}$ observed among sampled smoked fish could be attributed to the different processing, differences in the type of wood used for smoking process or even differences in construction of smoking kilns. BaP in smoked fish come from the wood smoke findings to work done elsewhere (Stolyhwo and Sikorski, (2005). 
Manal A. Atwa.

Traditional commercial smoking techniques, in which smoke from incomplete wood burning came into direct contact with the product, can lead to its considerable contamination with various PAHs, if the process is not adequately controlled. Critical treatments include temperature, time, humidity, types of control and smoke used (natural or generated), and the design and types of smokehouses or kilns effected on the PAHs contamination.

Visciano et al. (2006) studied the levels of PAHs in fresh and coldsmoked Atlantic salmon fillets and found no differences between raw and smoked samples in the concentrations of several carcinogenic PAHs, but significant differences for some low weight molecular PAHs, which confirmed that PAH concentrations in smoked fish are the result of both sea pollution and the smoking process.

Guillén and Sopelana (2004) investigated the possible presence of PAHs in 7 commercial types of cheese smoked by traditional techniques. In order to provide an indication of the PAH contamination in the cheeses that are commonly consumed. The samples were manufactured with milk from cows, sheep, goats, or a mixture of them, and purchased in local supermarkets. The results revealed the presence of several PAHs in the exterior zone of the samples, some of the PAHs having methyl groups. In all cases, the concentrations of PAH compounds of low molecular weight were much higher than those of high molecular weight.

Table (2): The BaP concentration in different kinds of coffee and tea

\begin{tabular}{|c|c|}
\hline Category of & $\frac{\text { Concentration of BaP }}{(u g / k g)}$ \\
\hline Turkish coffee (regular) & $\begin{array}{c}(\mu \mathrm{g} / \mathrm{kg}) \\
2.33-7\end{array}$ \\
\hline Turkish coffee with cardamom & 2.4 \\
\hline Dark Turkish coffee & 6.8 \\
\hline Dark Turkish coffee With herbal & 6.2 \\
\hline Medium Turkish coffee with herbal & 5.1 \\
\hline \begin{tabular}{|l|} 
Light Turkish coffee \\
\end{tabular} & 1.7 \\
\hline Light Turkish coffee with herbal & 0.9 \\
\hline American coffee Dark & 4.3 \\
\hline American coffee Medium & 3.7 \\
\hline American coffee Light & 2.1 \\
\hline Instant coffee & 2.9 \\
\hline Nescafe & 2.2 \\
\hline Espresso dark & 2.6 \\
\hline Espresso light & 1.5 \\
\hline Green coffee & ND -0.08 \\
\hline Green coffee with cardamom & 0.02 \\
\hline Green tea with jasmine flavor & 11 \\
\hline Tea powder & $0.5-7.9$ \\
\hline Dark tea powder & $1.46-9.2$ \\
\hline Cocoa powder & $0.035-0.05$ \\
\hline
\end{tabular}




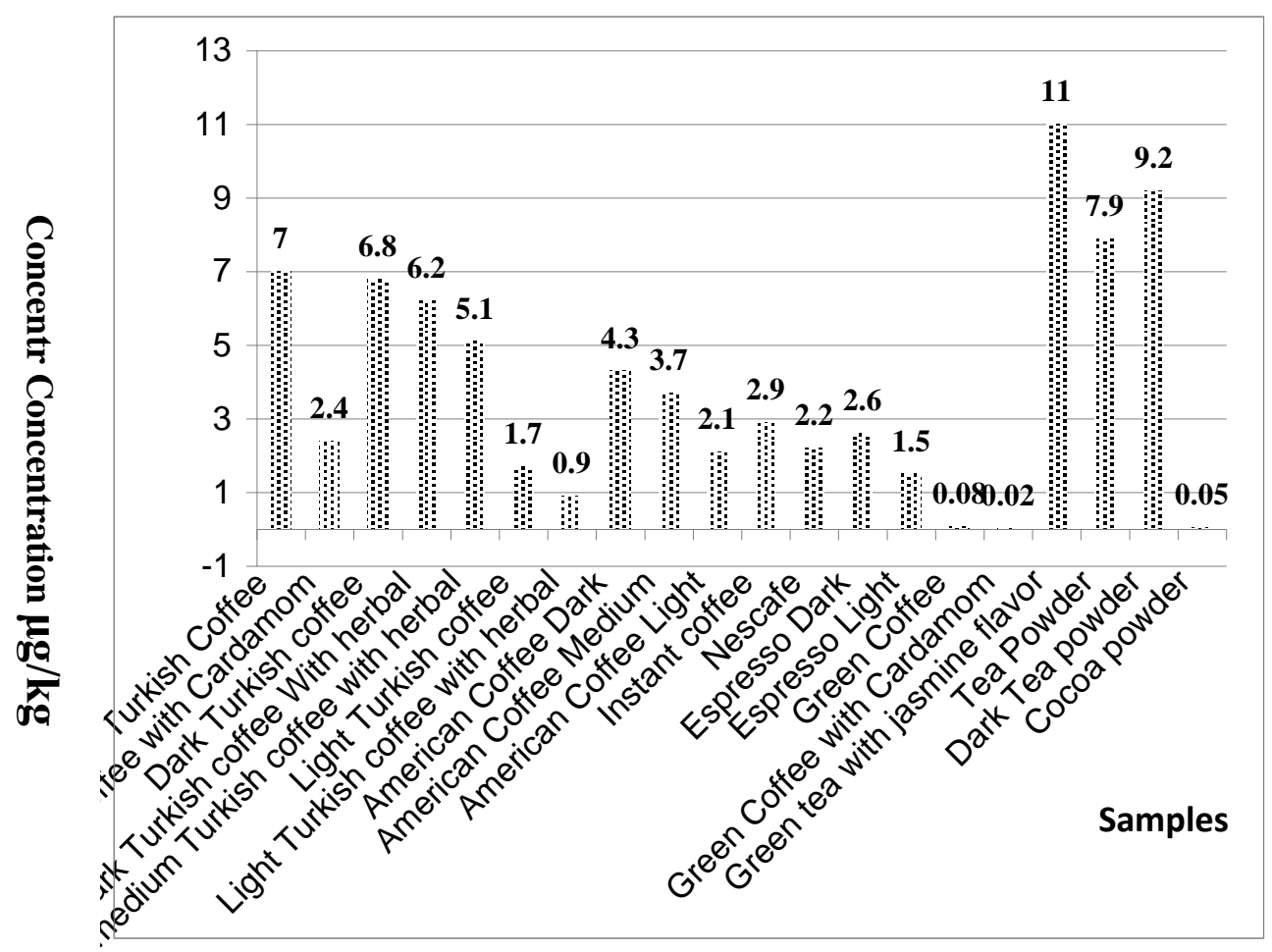

Fig (1): The BaP concentrations in experimental kinds of coffee and tea samples .

Roasting is a critical process in coffee production as it enables the development of flavor and aroma. At the same time, roasting may lead to the formation of no desirable compounds, such as polycyclic aromatic hydrocarbons (PAHs) Contamination of PAHs by intense thermal processing occurred due to generation by direct pyrolysis of food nutrients. Also due to direct deposition of PAHs from smoke of different thermal agents (Luch, A., 2005).

According to existing regulations by European Commission (2005) the content of BaP in some foods and baby foods should not be exceed 1 ppb.

Benzo (a) pyrene was detected in more than $95.8 \%$ of coffee, tea and cocoa 24 tested samples which amounted in range of 0.02 to $11 \mathrm{ppb}$ (Table 1). BaP detected in most samples are higher than the permissible limit (1 ppb) set by European Commission(2005). In eighteen coffee samples ,fourteen samples had upper values for the exceeding $1 \mu \mathrm{g} / \mathrm{kg}$.

The content of $\mathrm{BaP}$ in strong roasting coffee samples (dark) was higher than moderate or lighter roasting process with the highest average values of $7,6.8$ and $6.2 \mu \mathrm{g} / \mathrm{kg}$, respectively. This might be because high temperatures $\left(400-500^{\circ} \mathrm{C}\right)$ and long heating times were used for roasting. 
Manal A. Atwa.

The highest value in this category was in jasmine flavored green tea with value of $11 \mu \mathrm{g} / \mathrm{kg}$. In the cocoa powder there was a negligible amount of $\mathrm{BaP}$.

Table: (3) The BaP concentrations in different oil and fat samples

\begin{tabular}{|c|c|}
\hline Category of & Concentration of BaP \\
\hline (oil and fat samples) & $(\mu \mathrm{g} / \mathbf{k g})$ \\
\hline Imported extra virgin olive oil & 1.1 \\
\hline Imported virgin olive oil & 0.99 \\
\hline Refined olive oil & 0.97 \\
\hline Crude pomace oil & 2.38 \\
\hline Local extra virgin oil & 1.2 \\
\hline Local virgin olive oil & 1.4 \\
\hline Local ordinary olive oil & 0.69 \\
\hline Cold press olive oil & ND -0.4 \\
\hline Mix oils (palm, soya - olien) & 3.3 \\
\hline Corn oil & 1.2 \\
\hline Palm oil & 2.1 \\
\hline Sesame oil thermal extract & 49 \\
\hline Sesame oil extract on cold & ND - 2.6 \\
\hline Canola oil & 0.92 \\
\hline Sun flower oil & 2.1 \\
\hline Flax seed oil & 3.6 \\
\hline Flax seed oil on cold press & 1.0 \\
\hline Coconut oil & 6.7 \\
\hline Cocoa butter & $0.1-1.7$ \\
\hline Butter & ND \\
\hline Veg oil from (sardines cans) & 0.4 \\
\hline Veg oil from (Anchovies) & ND - 0.66 \\
\hline Veg oil from (Tuna) & ND - 0.12 \\
\hline Veg oil from (Mackerel) & 0.16 \\
\hline Veg oil from (Smoked Tuna) & 1.89 \\
\hline Veg oil from (Smoked Sardines) & 4 \\
\hline Veg oil from (Cheese) & ND \\
\hline Veg oil from (Pickles) & ND \\
\hline
\end{tabular}

Veg = vegetable

However, since benzo[a]pyrene is considered a carcinogenic compound, monitoring the amount of this compound in a popular drink such as coffee is crucial. So; the assessing of the dietary exposure of consumers to carcinogens is a significant.

Studies showed that the PAHs concentration in the roasted coffee beans was dependent on roasting temperature and roasting time. The content of low molecular PAHs, such as phenanthrene, fluoranthene, and pyrene was increased during the roasting process under elevated temperatures above $220^{\circ} \mathrm{C}$. Strong roasting conditions $\left(260^{\circ} \mathrm{C}\right)$ led to significant levels of pyrene, chrysene and benzo[a]anthracene. While the 
presence of PAHs in coffee has been attributed to their formation during the roasting step. The transfer of PAHs from coffee powder to coffee brew during coffee making has been reported to be relatively low; (García Falcón et al., 2005). This may be due to the low solubility of PAHs in water. ( $1 \%$ or less) of benzo[a]pyrene initially present in the solid coffee.

Since infusion strength influenced the transferred benzo[a]pyrene concentrations, higher transfer percentages up to $26 \%$ with the mean value of $5 \%$ were found by Maier (1991). More recently Houessou et al. (2007) reported a transfer percentage to vary from 0.6 to $30.9 \%$ for benz[a]anthracene, chrysene and benzo[ $b]$ fluoranthene depending on the $\mathrm{PAH}$ compound, which was slightly lower extractability for dark-roasted coffee as compared to light-roasted coffee.

More than 5 dried tealeaf samples had BaP contents varied between 0.5 and $11 \mu \mathrm{g} / \mathrm{kg}$ in which $80 \%$ of the samples exceeding $1 \mu \mathrm{g} / \mathrm{kg}$. However, preparation of the tea will dilute the level found in the beverage before consumption(Maier,1991).

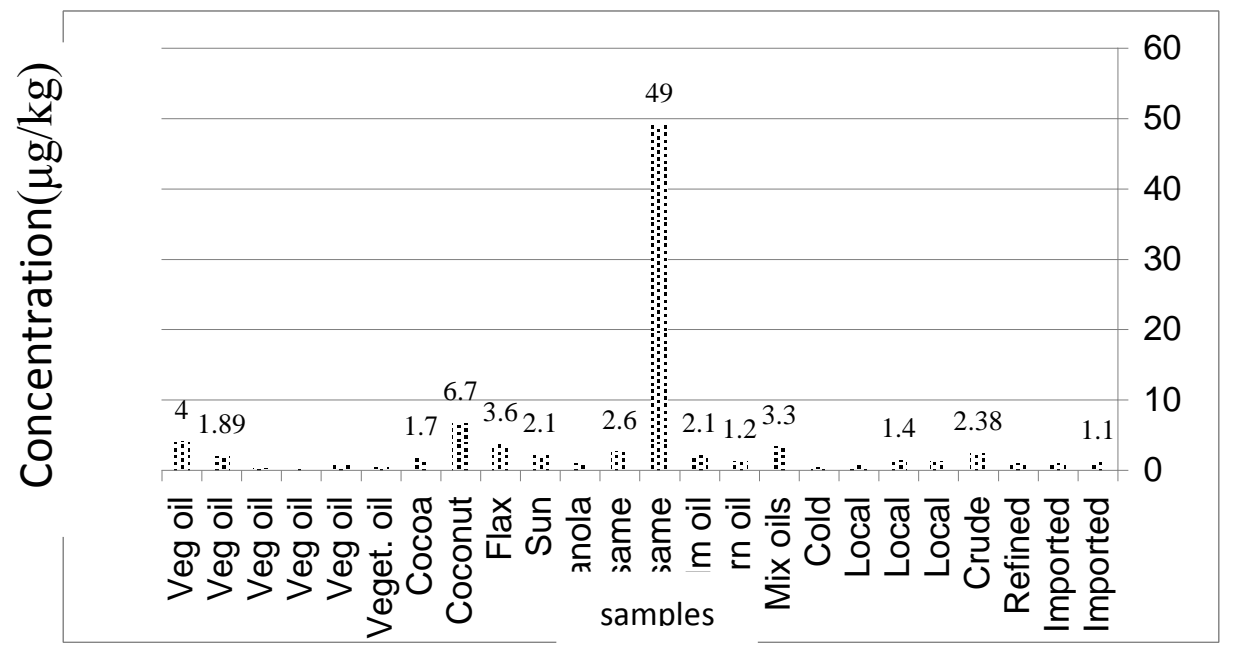

Fig(2): The BaP concentrations in different oil and fat samples

The concentrations of $\mathrm{BaP}$ in more than 30 oil samples ranged from 0.4 to $49 \mu \mathrm{g} / \mathrm{kg}$. The highest value was reported in roasted sesame oil samples also from local market while the least was reported in cold press olive oil samples from local market. In butter, vegetable oil associated with pickles and cheeses there were no detectable level of BaP;

In cold press olive oil and sesame levels of $\mathrm{BaP}$ were significantly lower 0.4 and 2.6 as compared to the thermal press oils samples as presented in Table ( 3 ).

The levels of $\mathrm{BaP}$ in virgin olive oil and olive oil was between 0.4 and $1.4 \mu \mathrm{g} / \mathrm{kg}$; but olive-pomace oil contained high level of BaP ( $2.38 \mu \mathrm{g} / \mathrm{kg})$. 
Manal A. Atwa.

Benzo(a)pyrene concentrations were below the allowed limit of the European Union $(2 \mu \mathrm{g} / \mathrm{kg})$ in $68 \%$ of the oil samples; These values are in agreement with most literature data for European oils (Preedy, 2010; Moret,2000 ;Conte, 2000 and Ballesteros , 2006).

Similar values of $\mathrm{BaP}$ were found for treated and non-treated oils, because the refined process eliminate the light PAHs (2-3 benzene rings), while the heavy PAHs (4-5 benzene rings, e.g. BaP), remain in the oil (Moret and Conte, 2000).

The benzo (a) pyrene content in aqueous enzymatic extracted oil and cold pressing oil can meet the safety need without refining. The major cause of forming excessive benzo (a) pyrene in traditional solvent extracted oil may be due to high temperature, rather than solvent. Neutralizing could lead to obvious increase in benzo (a) pyrene content in oil, and deodorizing lead to slight increase. But the processes of bleaching and winterization could reduce benzo (a) pyrene content in the oil to a safety range.

For the more than 30 vegetable oils analyzed samples in (vegetable oil associated with canned fish) the smoked sardine and tuna contained the highest levels of $\mathrm{BaP}$ ( 4 and $1.89 \mu \mathrm{g} / \mathrm{kg}$ respectively). It is possible that these high levels in the oil might result from leaching the lipophilic BaP from the smoked fish products. This behavior was also observed by Lawrence and Weber (1984) when they analyzed smoked mussels and oysters in vegetable oil. Although, in general the $\mathrm{BaP}$ values were low. Four samples (tuna, mackerel, sardines and anchovies) showed a BaP level less than $1 \mu \mathrm{g} / \mathrm{kg}$, the maximum that the EU intends to set for foods.

Table (4): The BaP concentrations in charcoal barbecued food samples

\begin{tabular}{|l|c|}
\hline $\begin{array}{l}\text { Category of } \\
\text { charcoal barbecued samples }\end{array}$ & Concentrations of BaP $(\boldsymbol{\mu g} / \mathbf{k g})$ \\
\hline Sausage & 3.24 \\
\hline Chicken & 10.2 \\
\hline Chicken skin & 27.34 \\
\hline Fish & 4.3 \\
\hline Fish skin & 56.1 \\
\hline Shrimp & 8.9 \\
\hline Bread as a layer of kebab & 4.9 \\
\hline (Kebab) Lamb meat & 68 \\
\hline (Kebab) Beef meat & 24.2 \\
\hline Kofta) Minced meat & 37 \\
\hline Liver & 4.76 \\
\hline Corn & 1.6 \\
\hline
\end{tabular}




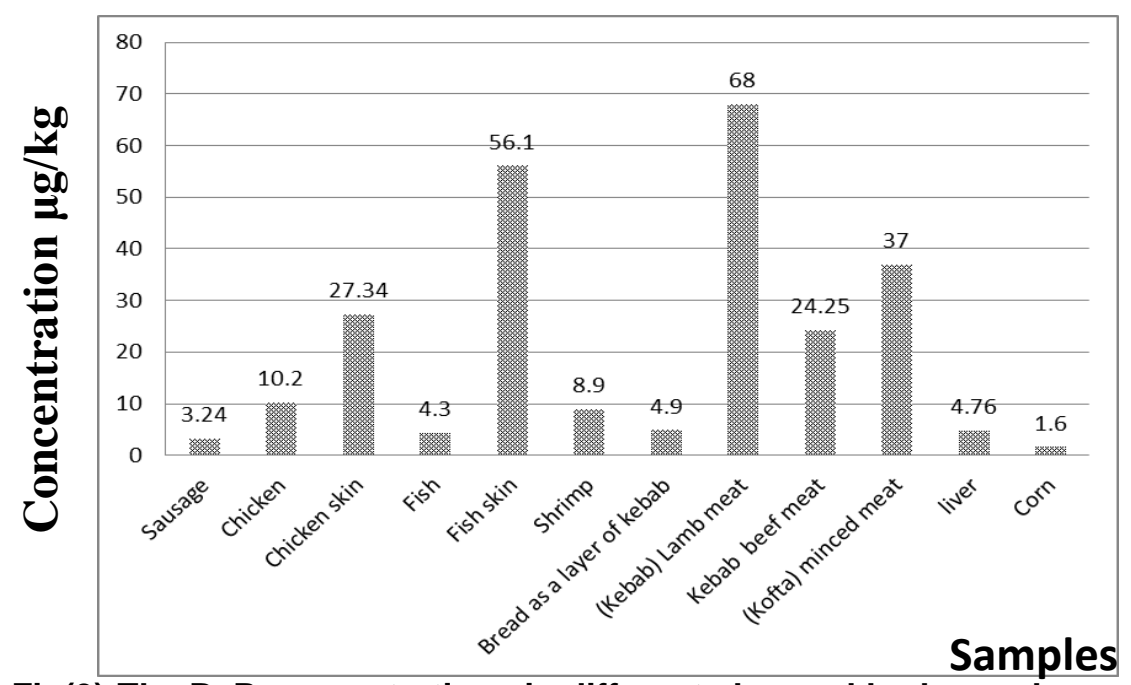

Fig(3):The BaP concentrations in different charcoal barbecued samples

The BaP contents in charcoal barbecued samples exceeding the EU limit are illustrated in Figure (3). Seen from this figure and table (4) the $\mathrm{BaP}$ contents those higher than $10 \mu \mathrm{g} / \mathrm{kg}$ were observed in six samples, including, kebab, kofta, and charcoal grilled chicken, with contents of 68,37 and $10.2 \mu \mathrm{g} / \mathrm{kg}$, respectively.

Twelves charcoal barbecued samples analyzed for BaP and $50 \%$ of the samples were exceeding the level set by European Commission regulations $(10 \mu \mathrm{g} / \mathrm{kg})$. Barbecuing with charcoal gave the highest benzo[a]pyrene levels in each type of food.

The strong influence of the cooking method and the type of heat source affected on the PAH levels in the processed food as demonstrated by Larsson et al. (1983).

$\mathrm{BaP}$ of charcoal barbecued lamb meat had around three folds the BaP level of beef meat sample prepared by the same process. The results indicated that $\mathrm{BaP}$ was mainly present in heat-treated animal source foods, which was considerably heavy BaP. From the results of the present study, it can be inferred that fat content might be an impacting factor for the generation of $\mathrm{BaP}$ in foods during food processing. Charcoal barbecued samples content of $\mathrm{BaP}$ ranged from $3.24 \mu \mathrm{g} / \mathrm{kg}$ in sausage sample to $68 \mu \mathrm{g} / \mathrm{kg}$ in lamb meat.

The influence of the fat content of the meat upon the amount of PAHs formed during charcoal grilling was also demonstrated by Mottier et al. (2000) who found significantly higher levels of carcinogenic PAHs in high fat containing lamb sausages compared to other meat products with lower fat content.

In traditional charcoal barbecued corn had BaP content of $1.6 \mu \mathrm{g} / \mathrm{kg}$; while the topped kebab charcoal barbecued bread had value of $\mathrm{BaP} 4.9 \mu \mathrm{g} / \mathrm{kg}$. This trend is conflict with what was reported in a previous study, where ReySalgueiro et al.(2008) reported that BaP did not generate until bread was heated to $300^{\circ} \mathrm{C}$, and the contents were lower than $0.5 \mu \mathrm{g} / \mathrm{kg}$. 
Manal A. Atwa.

Liver and shrimp samples showed moderate level of BaP which were 4.76 and 8.9 respectively; while the minced meat (kofta ) sample gave high ratio of $\mathrm{BaP} 37 \mu \mathrm{g} / \mathrm{kg}$.

On the other hand, benzo[a]pyrene contents were 10 times lower in fish than in fish skin; also, the chicken skin contents of BaP were three time higher than chicken (table 4 and fig. 3).

Kebab is made from fillets of meat stacked on a horizontal (charcoal) grill close to the heat source and this helps to account for its rich flavor and it became popular as well. This indicated that a certain carcinogenic risk of $\mathrm{BaP}$ for public health comes from charcoal-grilled meat(EFSA, 2008) .

In a recent study, White et al.(2008) investigated the effects of frying, grilling, barbecuing, toasting and roasting on the formation of PAHs in foods prepared in the home and from catering outlets, barbecuing with charcoal plus wood chips gave the highest benzo[a]pyrene levels in each type of food, In general PAH levels were increased when the food was cooked closer to the heat source.( $E F S A, 2008)$

Smoked sausages cased in cellophane casings. The levels of benzo[a]pyrene in the latter samples were lower than those found in the chorizo samples(Gillbert and Knowles, 1975). The authors explained the difference by the hydrophilic nature of cellophane, which renders it essentially impermeable to the PAHs. In contrast, the natural casings, being primarily protein and lipid, are more likely to absorb such hydrophobic compounds, thus allowing diffusion and hence penetration to take place.

Lijinsky and Ross (1967) studied the effect of variation in methods of cooking meat on the content of benzo[a]pyrene and other PAHs in the prepared food. They showed that PAHs arised from the pyrolysis of fat which drips to the heat source. The amount produced increased paralleled with increased fat content, longer exposure of the food to the flames and closeness to the heat source.

The grilling of frankfurters in the flames of a log fire resulted in extremely high PAH contents, up to $212 \mu \mathrm{g} / \mathrm{kg}$ benzo[a]pyrene.

Table (5) : The BaP concentrations in experimental kinds of different types of food samples

\begin{tabular}{|l|c|c|c|}
\hline \multirow{2}{*}{$\begin{array}{l}\text { Category of } \\
\text { (miscellaneous) samples }\end{array}$} & \multirow{2}{*}{$\begin{array}{c}\text { Samples } \\
\text { tested }\end{array}$} & \multicolumn{2}{|c|}{$\begin{array}{c}\text { concentrations of BaP } \\
(\boldsymbol{\mu g} / \mathbf{k g})\end{array}$} \\
\cline { 3 - 4 } & & Minimum & Maximum \\
\hline $\begin{array}{l}\text { Dried fruit(fig, raisin, prunes \& } \\
\text { cherries) }\end{array}$ & 4 & 0.13 & 0.29 \\
\hline Spices(mixed) & 2 & $\mathrm{ND}$ & 3.1 \\
\hline Nuts(kajo, almond) & 2 & 0.15 & 0.26 \\
\hline Chocolates & 1 & 0.1 & \\
\hline Cereals (cornflakes) & 2 & $\mathrm{ND}$ & 0.34 \\
\hline Processed fruits( cocktail ) & 1 & $\mathrm{ND}$ & \\
\hline Light soya sause & 1 & 1.6 & \\
\hline Dark Soya sauce & 2 & 1.6 & 2.6 \\
\hline Infant food & 1 & $\mathrm{ND}$ & \\
\hline
\end{tabular}


Among 16 different samples of nuts, spices, soya sauce, cereals, chocolates and infant formula tested appeared to contain low levels of $\mathrm{BaP}$ ranged from zero in four samples to $0.34 \mu \mathrm{g} / \mathrm{kg}$ in one kind of cornflakes which comply with the EU regulations compared to the dark soya sauce samples which were relatively higher (equal to 1.6 to2.6 $\mu \mathrm{g} / \mathrm{kg}$, respectively),these contents were found to be lower than the EU limit.

Finally, a wide variation was observed for $\mathrm{BaP}$ contents of the heattreated foods between different food types. As seen from our results, there were more than $80 \%$ out of analyzed samples exceeding the level set by EU regulations, the minimum contents of $\mathrm{BP}$ were found in cocoa powder 0.02 $\mu \mathrm{g} / \mathrm{kg}$ in which the highest contents were found in charcoal lamb meat 68 $\mu \mathrm{g} / \mathrm{kg}$.

There were no significant differences between the results of the two instruments (GC and HPLC-FD).

\section{REFERENCES}

ATSDR. (1996). "Toxicological profile for polycyclic aromatic hydrocarbons." Agency for Toxic Substances and Disease Registry, Atlanta, GA:U.S. department of Health and Human Services, Public Health Service.

Balenovic J., Petrovic, I. and Perkovac, M. (1995) Enrichment of benzo[a]pyrene in vegetable oils and determination by HPLC-FL Euro Food Chem .8, 275-281.

Ballesteros E., Garcia Sanchez A. and Ramos Martos N. Simultaneous multi-determination of residues of pesticides and polycyclic aromatic hydrocarbons in olive and olive-pomace oils by gas chromatography/tandem mass spectrometry. J. Chromatogr. A.;1111:89-96.

Bordajandi, L. R., Dabrio, M., Ulberth, F. and Emons, H. (2008). Optimization of the GC-MS conditions for the determination of the $15 \mathrm{EU}$ foodstuff priority polycyclic aromatic hydrocarbons.Separation sci.31:1769-1778.

Chan, Gu, J ; LS; Wong, CK; et al. (2011) Effect of benzo[a]pyrene on the production of vascular endothelial growth factor by human eosinophilic leukemia EoL-1 cells. J Environ Pathol Toxicol Oncol 30(3):241-249.

Chen, B. H. and Chen, Y. C. 2001. Formation of polycyclic aromatic hydrocarbons in the smoke from heated model lipids and food lipids. J. Agric.food chem. 49: 5238-5243.

Commission Regulations,( 2006) 1881/EC European Commission. Setting maximum levels for certain contaminations in foodstuffs, Brussels.

Culotta, L., Melati, M. R. and Orecchio, S. (2002). The use of leaves of Rosmarinus officinalis $\mathrm{L}$. as samplers for polycyclic aromatic hydrocarbons. Annali di Chimica 92: 837-845.

EC (European Commission). (2001). Outcome of the expert group meeting on 3 October on waysto prevent contamination of olive residue oil and other oils with polycyclic aromatic hydrocarbons (PAH). Summary 
Manal A. Atwa.

record of the 85th meeting of the Standing Committee on Foodstuffs, 25th October 2001, agenda item 9.

E.C (European Commission)( 2005)a. Commission recommendation on the further investigation into the levels of polycyclic aromatic hydrocarbons in certain foods. Notified under document number C (2005/256) (2005/108/EC). Official J. Eur Union 314: 4-9.

E.C (European Commission)( 2005)b. Directive No. 208/2005 of 4 February 2005, amending Regulation (EC) No. 466/2001 as regards polycyclic aromatic hydrocarbons. Official J. Eur .Union, Brussels, Belgium.

EFSA (European Food Safety Authority). (2008). Guidance Document for the Use of the Concise European Food Consumption Database in Exposure Assessment. http: // www.efsa.europa. eu/ EFSA/ General/ Coincise_database_guidance_document_and_anne

Garcı'a Falco'n, M.S. , Gonza'lez Amigo S., LageYusty M.A., Laffon Lage B. and Simal Lozano (1999). Application of the effects of solvent and dissolved oxygen on the determination of benzo[a]pyrene by constantwavelength synchronous spectrofluorimetry in smoke-flavouring Talanta, 48 . 377-384.

García-Falcón, M.S., Cancho-Grande, B. and Simal-Gándara, J. (2005). Minimal clean-up and rapid determination of polycyclic aromatic hydrocarbons in instant coffee. Food Chem. 90: 643-647.

Gilbert, J. and Knowles, M.E. (1975). The chemistry of smoked foods: a review. International J. Food Sci. and Techno. 10(3): 245-261.

Grimmer G. and Bohnke H. (1975). Detoxication of Structurally Diverse Polycyclic Aromatic Hydrocarbon (PAH) o-Quinones by Human Recombinant Catechol-O-methyltransferase (COMT) via O-Methylation of PAH Catechols. Assoc J. off. Anal. Chem. 58725-733.

Guillén, M.D. and Sopelana, P. (2004). Occurrence of polycyclic aromatic hydrocarbons in smoked cheese. J. Dairy Sci. 87: 556-564.

Guillén, M.D., Sopelana, P., and Partearroyo, M.A. (1997). Food as a source of polycyclic aromatic carcinogens. Rev. Environ. Health, 12: 133-146.

Hecht S.S., Carmella S.G., Villalta P.W. and Hochalter J.B.(2010) Analysis of phenanthrene and benzo[a]pyrene tetraol enantiomers in human urine: Relevance to the bay region diol epoxide hypothesis of benzo[a]pyrene carcinogenesis and to biomarker studies. Chem. Res. Toxicol. 2010;23:900-908.

Hossain, M. A., Salahuddin, S. M., Hanif, A. M. and Pankaj, K. K. 2009. Carcinogenic polycyclic aromatic hydrocarbon, anthracene in cabbage samples from Bangladesh.Asian J.Food and Agro-Industry 2: 315-320.

Houessou, J.K., Benac, C., Delteil, C. and Camel, V. (2005). Determination of polycyclic aromatic hydrocarbons in coffee brew using solid-phase extraction. J. Agric. Food Chem. 53: 871-879.

Houessou, J.K., Maloug, S., Leveque, A.-S., Delteil, C., Heyd, B. and Camel, V. (2007). Effect of roasting conditions on the polycyclic aromatic hydrocarbon content in ground Arabica coffee and coffee brew. J. Agric. Food Chem. 55: 9719-9726. 
Houessou, J.K., Goujot, D., Heyd, B. and Camel, V. (2008). Modeling the formation of some polycyclic aromatic hydrocarbons during the roasting of Arabica coffee samples.J.Agric.Food Chem. 56: 3648-3656.

Howard, J.w., Teague R.T., White R.H., Fry Jr , B.E., (1966) Extraction and estimation of polycyclic aromatic hydrocarbons in smoked foods. I. General Method. J.AOAC 49,595-611.

IARC(1987) International Agency for Research on Cancer. Monographs on the evaluation of the carcinogenic risk of chemicals to humans.Overall evaluation of carcinogenicity:An updating of IARC monographs,pages $1-42$.

Laffon Lage B., Garci'a Falco'n M.S., Gonza'lez Amigo S., Lage Yusty M.A., Simal Lozano(1997)Comparison of supercritical fluid extraction and conventional liquid-solid extraction for the determination of benzo[a]pyrene in water-soluble smoke.J.,Food Addit.Contam.14(5) 469-470.

Larsson, B.K. (1983). Polycyclic aromatic hydrocarbons. Internal report, 1983-10-19. National Food Administration, Uppsala, Sweden.

Lawrence,J.F.and Weber,D.F.(1984).Determination of polycyclic aromatic hydrocarbons in some Canadian commercial fish,shellfish and meat products by liquid chromatography with confirmation by capillary gas chromatography-massspectrometry.J.AgricandFood Chem32:789-794.

Leadon, SA; Stampfer, MR and Bartley, J. (1988) Production of oxidative DNA damage during the metabolic activation of benzo[a]pyrene in human mammary epithelial cells correlates with cell killing. Proc Natl Acad Sci U S A 85(12):4365-4368.

Lijinsky, W. and Ross, A.E. (1967). Production of carcinogenic polynuclear hydrocarbons in the cooking of food.Food Cosmet. Toxicol. 5: 343-347.

Luch, A. (2005). The carcinogenic effects of polycyclic aromatic hydrocarbons. London: Imperial College Press. ISBN 1-86094-417-5.

Maier, H.G. (1991). Teneur en composés cancérigènes du café en grains. Café, cacao, Thé , Food Agric Immunol, 35(2) : 133-142.

Moret S., Conte L.S. (2000) Polycyclic aromatic hydrocarbons in edible fats and oils: Occurrence and analytical methods. J. Chromatogr. A.; $882: 245-253$.

Moret, S., Purcaro, G. and Conte, I. S. (2005). Polycyclic aromatic hydrocarbons in vegetable oils from canned foods. Eur. J. Lipid Sci. Techno. 107: 488-496.

Mottier, P., Parisod, V. and Turesky, R.J. (2000). Quantitative determination of polycyclic aromatic hydrocarbons in barbecued meat sausages by gas chromatography coupled to massspectrometry. J. Agric. Food Chem. 48: 1160-1166.

Orecchio, S. and Papuzza, V. 2008. Levels, fingerprint and daily intake of polycyclic aromatic hydrocarbons in bread baked using wood as fuel. J. of Hazardous Materials 164: 876-883.

Phillips, D.H. (1999). Polycyclic Aromatic Hydrocarbons in the Diet. Mutat. Res., 443: 139- 147. 
Manal A. Atwa.

Preedy V.R., Watson R. (2010) olives and olive oil in health and disease prevention. Academic Press; Waltham, MA, USA: 2010.

Pupin A.M.and Figuiredo Toledo M.C.(1996)Food Addit. Contam.13 639-646.

Ramalhosa, M. J., Paula, P., Simone, M., Cristina, D. and Beatriz, P. O. (2009). Analysis of polycyclic aromatic hydrocarbons in fish: Evaluation of a quick, easy, cheap, effective, rugged and safe extraction method. J. Separation Sci. 32: 3529-3538.

Rey-Salgueiro, L.; Martinez-Carballo, E.; Garcia-Falcon, M.S.and SimalGandara, J.(2008) Effects of a chemical company fire on the occurrence of polycyclic aromatic hydrocarbons in plant foods. Food Chem., 108, 347-353.

Rybicki B.A., Nock N.L., Savera A.T., Tang D.and Rundle A. (2005)Polycyclic aromatic hydrocarbon-DNA adduct formation in prostate cancerogenesis. Cancer Lett.;239:157-167.

Santana, R. , Sosa F., Talanta (1992). Enrichment of benzo[a]pyrene in vegetable oils and determination by HPLC-FL,39. 1611-1617.

SCF Scientific Committee on Food (2002), EUROPEAN COMMISSI ON HEALTH and CONSUMER PROTECTION DIRECTORATEGENERALSCF/CS/CNTM/PAH/29

Speer, K., Steeg, E., Horstmann, P., Kühn, T. and Montag, A. 1990. Determination and distribution of polycyclic aromatic hydrocarbons in native vegetable oils, smoked fish products, mussels and oysters, and bream from the river Elbe. J. High Res. Chrom., 13: 104-111.

Stolyhwo, A. and Sikorski, Z. E. (2005). Polycyclic aromatic hydrocarbons in smoked fish: A critical review. Food Chem. 91: 303-311.

Van Stijn F., Kerkhoff M.A.T., Vandeginste B.G.M. (1996), Determination of polycyclic aromatic hydrocarbons in edible oils and fats by on-line donor-acceptor complex chromatography and HPLC with fluorescence detection. Chromatogr J. A 750 263-273.

Visciano, P., Perugini G., Amorena M. and lanieri, A. (2006). Polycyclic aromatic hydrocarbons in fresh and cold-smoked Atlantic salmon fillets. J. Food Prot. 69: 1134-1138

White, S., Fernandes A. and Rose, M. (2008). Investigation of the formation of PAHs in foods prepared in the home and from catering outlets to detremine the effects of frying, grilling, barbecuing, toasting and roasting. FD 06/13.) Food Standard Agency (FSA)/Central Science Laboratory (CSL).

Yusty, M. A. and Davina, C. J. (2005). Supercritical fluid extraction and high performance liquid chromatography-fluorescence detection method for polycyclic aromatic hydrocarbons investigation in vegetable oil. Food Control 16: 59-64. 


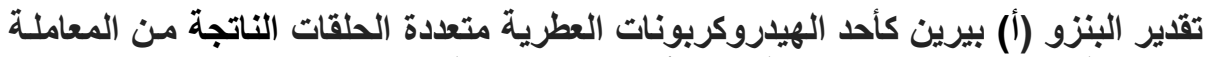

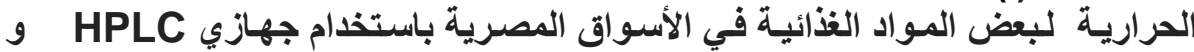

GC-1أ-

منال عبد المطلع عطوه

\section{المركز الاقليمي للاغذية والمئ عوه والاعلاف ـ مركز البحوث الزراعية}

وتهدف هذه الدراسة إلى قياس واحد من أهم الهيدروكربونات العطرية المتعددة الحلقات و هو البنات العزو (أ) بيرين باعنباره

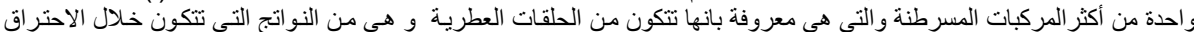

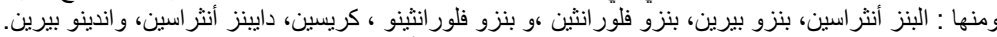

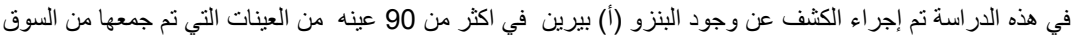

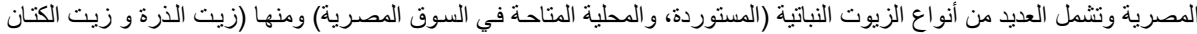

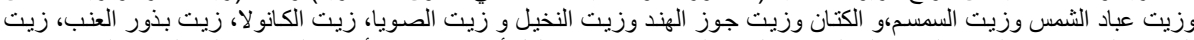

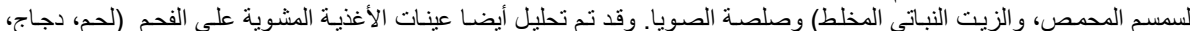

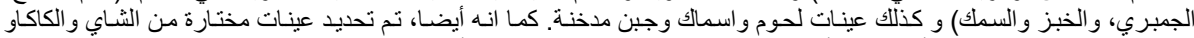

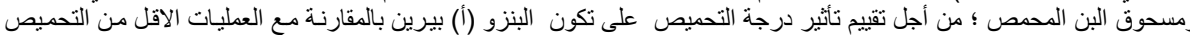
وكذلك بذور القهوة الخضر الثرئ

و قد تفاوت تركيز البنزين (أ) بيرين في العينات الدخخنة. وسجلت اقل تركيز في عينة الجبن المستوردة الدخخنة بينما

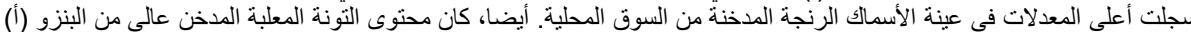

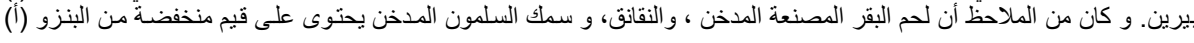
و بالبحث ثبت ان حو الي 30٪ من عينات الاغذية المدخنه في هذه الدراسة لديها مستويات من مـادة البنزو (أ) بيرين

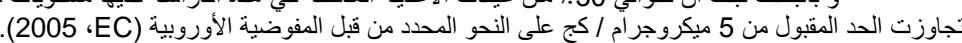

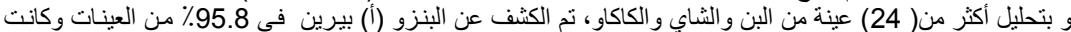

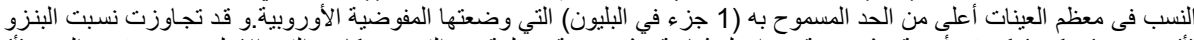

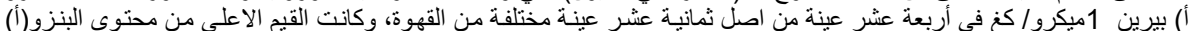

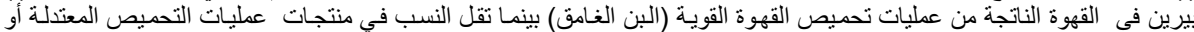

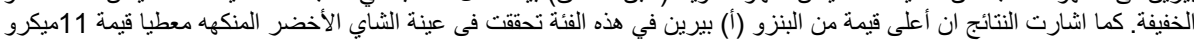

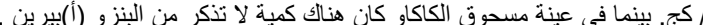

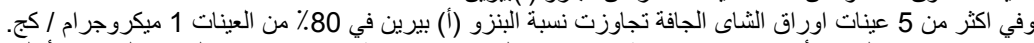

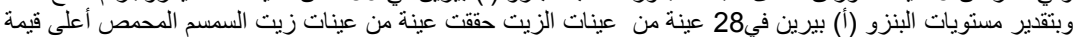

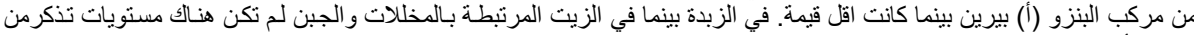

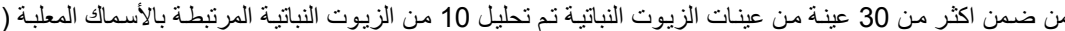
البنزو (أ) بيرين البنزو

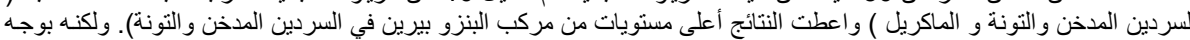

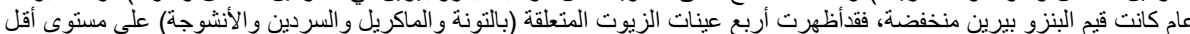

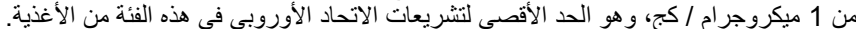

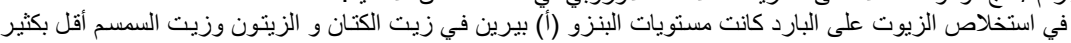

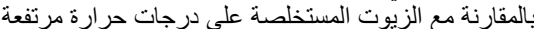
وكانت المستويات في "زيت الزيتون البكر " و "زيت الزيتون" متوسطة بينما تضمن زيت ثنفل الزيتون مستويات عالية من البنزو (أ) بيرين.

في عينات المكسر ات و الفو اكه الدجفة، الحبوب، ،الثوكو لاته و حليب الأطفال تر اوح محتوى البنزو بيرين من السالب إلى الكى

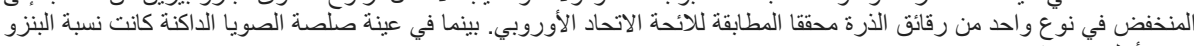
برين أعلى نسيبا.

و واكدت النتائج علي ان50٪ من العينات من الاغذية المشوية على الفحم قد تجاوزت المستوى المحدد من البنزوبيرين .

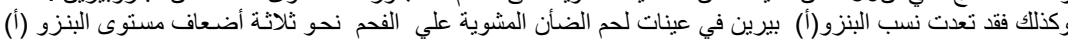

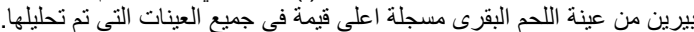

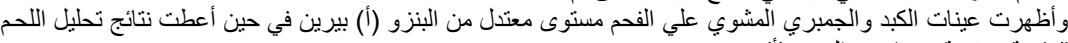
المفروم (الكفتة) قيمة مرتفعة نسبيا من البنزو (أ) بيرين الكين

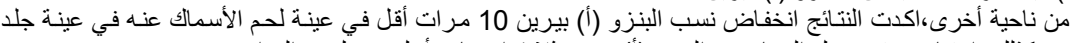
السمك المشوى. وكذلك، ارتفاع محتوى جلد الدجاج من البنزو (أ) بيرين ثلاث اضعاف العن أعلى من لحوم الدواجن. 